\title{
CYANOSIS WITHOUT SULF- OR METHEMOGLOBINEMIA IN PATIENTS RECEIVING SULFANILAMIDE TREATMENT
}

\author{
By LEON C. CHESLEY \\ (From the Department of Biochemistry, Margaret Hague Maternity Hospital, Jersey City)
}

(Received for publication March 9, 1938)

Cyanosis is very frequently observed in patients receiving sulfanilamide therapy. This cyanosis seems to be almost generally attributed to sulfhemoglobinemia or methemoglobinemia, though few writers have actually identified these derivatives in cyanotic patients.

Colebrook and Kenny (1) in an early report, stated that three of thirty-eight patients developed sulfhemoglobinemia, as shown by spectroscopic examination of the blood. Several other papers mention the proved occurrence of sulfhemoglobinemia, especially when sulfanilamide and saline cathartics (such as magnesium sulphate) are given concurrently $(2,3)$.

Marshall and Walzl (4) determined the total hemoglobin from the blood iron in five cyanotic patients, and made simultaneous measurements of the oxygen capacity as an index to the active hemoglobin. Any deficit in oxygen capacity, relative to the total hemoglobin, would indicate inactive forms of hemoglobin such as sulf- or methemoglobin. They found only minimal amounts, if any, of such derivatives.

Mull and Smith (5) found, in their one case, a discrepancy between the total hemoglobin and the oxygen capacity which they took to mean that the blood was unable to load oxygen normally. They also found a high degree of oxygen unsaturation which they correlated with the abnormal oxygen uptake.

The present paper reports observations on eight patients who, in the past year, developed cyanosis with sulfanilamide treatment. The method was the same in principle as that of Marshall and Walzl (4).

\section{MATERIAL AND METHODS}

The number of patients receiving sulfanilamide therapy in this hospital is small, and but few who did receive the drug developed cyanosis. The last four patients to show cyanosis were used in this study-all had puerperal infections. Four other patients from the Jersey City Medical Center are included. The diagnoses are indicated in Table I.

In all cases oxalated venous blood was used. Simultaneous duplicate determinations of blood iron and carbon monoxide capacities were made.

Wong's (6) method was used for the determination of total blood iron. The theoretical carbon monoxide capacity was calculated from the blood iron on the assumption that all of the iron represented hemoglobin in some form. Since each mol ( 55.84 grams) of iron will combine with one mol (22.4 liters) of carbon monoxide, each milligram of iron will hold $0.4 \mathrm{cc}$. of $\mathrm{CO}$.

The carbon monoxide capacity was measured by the method of Van Slyke and Hiller (6), using $2 \mathrm{ml}$. samples of blood.

Methemoglobin was determined according to Van Slyke and Hiller (6).

Methemoglobin and sulfhemoglobin were prepared in washed cells taken from pregnant women. For methemoglobin, $10 \mathrm{mgm}$. of sodium nitrite were added to $20 \mathrm{ml}$. of cells suspended in saline. After 5 minutes, the cells were thrown down by centrifuging, and were washed three times in saline. They were then returned to the original plasma. Sulfhemoglobin was made by adding $10 \mathrm{mgm}$. of phenylhydrazine to $20 \mathrm{ml}$. of cells in saline, and saturating with hydrogen sulphide. After washing three times, the cells were returned to the plasma.

\section{RESULTS AND DISCUSSION}

In all eight cases, there was found no significant difference between the calculated and the measured $\mathrm{CO}$ capacities. This precludes the existence of more than minimal amounts of sulf- or methemoglobinemia in these patients, all of whom had cyanosis. The results are summarized in Table I.

Experiments were carried out with methemoglobin and sulfhemoglobin to determine whether sulfanilamide would enhance the $\mathrm{CO}$ capacity-a rather improbable possibility. The blood levels of 
TABLE I

The absence of sulf-and methemoglobinemia in patients showing cyanosis after sulfanilamide treatment

\begin{tabular}{|c|c|c|c|c|c|c|c|}
\hline Date & Diagnosis & $\begin{array}{c}\text { Cy- } \\
\text { ano- } \\
\text { sis }\end{array}$ & $\begin{array}{l}\text { Hemo- } \\
\text { globin }\end{array}$ & $\begin{array}{c}\text { Blood } \\
\text { iron }\end{array}$ & $\begin{array}{c}\text { Calcu- } \\
\text { lated } \\
\text { CO } \\
\text { capac- } \\
\text { ity }\end{array}$ & $\begin{array}{c}\text { Meas } \\
\text { ured } \\
\text { C0 } \\
\text { capac- } \\
\text { ity }\end{array}$ & $\begin{array}{l}\text { Possible } \\
\text { sulf- } \\
\text { and met- } \\
\text { bemo- } \\
\text { globin }\end{array}$ \\
\hline 1987 & \multirow{5}{*}{$\begin{array}{l}\text { Puerperal sepsis } \\
\text { Puerperal sepsis } \\
\text { Puerperal sepais } \\
\text { Septicemia after } \\
\text { hand infection } \\
\text { ? } \\
\text { Ear and brain } \\
\text { abecess } \\
\text { Scarlet fever } \\
\text { Puerperal sepsis }\end{array}$} & \multirow[b]{2}{*}{$\begin{array}{c} \pm \\
\pm \\
+ \\
++\end{array}$} & $\begin{array}{c}\text { grame } \\
\text { per } \\
100 \mathrm{ml} .\end{array}$ & $\begin{array}{c}\text { mom. } \\
\text { per } \\
100 \mathrm{ml} .\end{array}$ & poluenes & percmes & \multirow[b]{2}{*}{$\begin{array}{l}\text { None } \\
\text { None } \\
\text { None } \\
\text { Negligible }\end{array}$} \\
\hline $\begin{array}{l}\text { April } \\
\text { May } \\
\text { May } \\
\text { July }\end{array}$ & & & $\begin{array}{r}9.13 \\
9.24 \\
6.10 \\
12.65\end{array}$ & $\begin{array}{l}30.50 \\
30.95 \\
20.4 \\
42.4\end{array}$ & $\begin{array}{r}12.20 \\
12.38 \\
8.16 \\
16.96\end{array}$ & $\begin{array}{r}12.20 \\
12.39 \\
8.18 \\
16.90\end{array}$ & \\
\hline $\begin{array}{l}\text { August } \\
\text { October }\end{array}$ & & ++ & $\begin{array}{r}11.13 \\
7.86\end{array}$ & $\begin{array}{l}37.4 \\
26.3\end{array}$ & $\begin{array}{l}14.96 \\
10.52\end{array}$ & $\begin{array}{l}14.88 \\
10.32\end{array}$ & $\begin{array}{l}\text { Negligible } \\
\text { Negligible }\end{array}$ \\
\hline October 13 & & ++ & 7.42 & 24.8 & 9.92 & 9.81 & Negligible \\
\hline February 23 & & ++ & 9.06 & 30.3 & 12.12 & 12.06 & Negligible \\
\hline
\end{tabular}

sulfanilamide were always between 5 and 10 mgm. per cent, when determined. In these control experiments, therefore, concentrations of this order were maintained. As the data in Table II show, sulfanilamide has no effect upon the $\mathrm{CO}$ capacity of either met- or sulfhemoglobin.

TABLE II

The failure of sulfanilamide to affect the $\mathrm{CO}$ capacity of met-and sulfhemoglobin

\begin{tabular}{|c|c|c|c|c|c|c|}
\hline \multicolumn{7}{|c|}{ Methemoglobin } \\
\hline & \multirow{2}{*}{$\begin{array}{c}\text { Hemo- } \\
\text { globin } \\
\text { plus } \\
\text { met- } \\
\text { hemo- } \\
\text { globin }\end{array}$} & \multirow[b]{2}{*}{$\begin{array}{l}\text { Active } \\
\text { hemo- } \\
\text { globin }\end{array}$} & \multicolumn{4}{|c|}{ Sulfanilamide } \\
\hline & & & 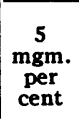 & $\begin{array}{c}10 \\
\text { mgm. } \\
\text { per } \\
\text { cent }\end{array}$ & $\begin{array}{c}20 \\
\text { mgm. } \\
\text { per } \\
\text { cent }\end{array}$ & 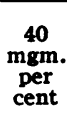 \\
\hline $\begin{array}{l}\text { CO capacity, } \\
\text { volumes per cent }\end{array}$ & $\begin{array}{r}13.85 \\
\text { (Hy } \\
\text { sulph }\end{array}$ & $\begin{array}{l}6.72 \\
\text { po- } \\
\text { lite) }\end{array}$ & 6.82 & 7.05 & 6.68 & 6.82 \\
\hline
\end{tabular}

Sulfhemoglobin

\begin{tabular}{l|c|c|c|c|c|c}
\hline & $\begin{array}{c}\text { Hemo- } \\
\text { globin } \\
\text { plus } \\
\text { gulf- } \\
\text { hemo- } \\
\text { globin }\end{array}$ & $\begin{array}{c}\text { Active } \\
\text { hemo- } \\
\text { globin }\end{array}$ & $\begin{array}{c}5 \\
\text { mgm. } \\
\text { per } \\
\text { cent }\end{array}$ & $\begin{array}{c}10 \\
\text { mgm. } \\
\text { per } \\
\text { cent }\end{array}$ & $\begin{array}{c}20 \\
\text { mgm. } \\
\text { per } \\
\text { cent }\end{array}$ & $\begin{array}{c}40 \\
\text { mgm. } \\
\text { per } \\
\text { cent }\end{array}$ \\
\hline $\begin{array}{l}\text { CO capacity, } \\
\text { volumes per cent }\end{array}$ & $\begin{array}{c}16.93 \\
\text { (Iron) }\end{array}$ & 12.22 & 12.10 & 12.10 & 12.22 & 12.22 \\
\hline
\end{tabular}

Marshall and Walzl (4) found only one patient in seven (five of whom were cyanotic), in whom there was any methemoglobin. This patient had only a small amount of methemoglobinemia which almost certainly could not alone have caused the cyanosis. In the one case reported by Mull and Smith (5), there is the possibility that sulf- or methemoglobin existed. However, the oxygen unsaturation which they observed was perhaps sufficient to cause cyanosis from reduced hemoglobin alone, there being as high as eight grams of the reduced form.

This observation of Mull and Smith is well worth checking in a series of patients, for if such degrees of oxygen unsaturation do exist, the sulfanilamide is producing an anoxia. The frequent reactions to sulfanilamide such as headache, nausea, malaise, vertigo, lassitude, tinnitus, accelerated pulse and respiration, and loss of alkali in the urine constitute the syndrome of "mountain sickness" which is caused by an anoxic anoxia. If the drug does have this effect, perhaps the customary use of sodium bicarbonate with sulfanilamide is not wholly desirable. The excretion of alkali with the fall in blood $\mathrm{CO}_{2}$ combining power would appear to be a compensatory response to the loss of carbon dioxide blown off during the accelerated respiration. Also sulfanilamide has been recommended in treating pneumonia. In pneumonia, anoxia is often already a serious complication.

The fact that Marshall and Walzl (4) with 7 cases, Mull and Smith (5) in one case, and the writer, 8 cases, have not found sulf- or methemoglobinemia in high enough concentration to cause noticeable cyanosis casts serious doubt upon the prevalent idea that cyanosis following sulfanilamide is usually attributable to these hemoglobin derivatives. This is not to deny that in some cases the cyanosis may be so caused. Discombe (2) did find considerable sulfhemoglobinemia in six of seven cases. He has attributed this to the concurrent use of magnesium sulphate which presumably causes an enterogenous sulfhemoglobinemia perhaps catalyzed by sulfanilamide. Paton and Eaton (3) found four out of nineteen patients to have a methemoglobinemia, which was proved spectroscopically. In the present series, no patient was allowed saline cathartics, which might account for the absence of sulfhemoglobin.

From this we can only conclude that before attributing the cyanosis in a given case to sulf- or methemoglobinemia, these pigments must be identified, and shown to be present in such concentra- 
tion as would give the observed degree of cyanosis.

What the actual mechanism of the usual cyanosis is one cannot say. Marshall and Walzl (4) suggested that a black oxidation product of sulfanilamide might possibly stain the erythrocytes. Perhaps, as Mull and Smith's data suggest, reduced hemoglobin is responsible. This would preclude cyanosis in severely anemic patients.

\section{SUMMARY}

Sulf- and methemoglobinemia were ruled out in eight patients showing cyanosis after sulfanilamide therapy. The theoretical carbon monoxide capacities calculated from the blood irons, and the measured CO capacities check closely. Therefore all hemoglobin is present in an active form.

\section{BIBLIOGRAPHY}

1. Colebrook, L., and Kenny, M., Treatment of human puerperal infections, and of experimental infections in mice, with prontosil. Lancet, 1936, 1, 1279.

2. Discombe, G., Sulfhaemoglobinaemia following sulfanilamide treatment. Lancet, 1937, 1, 626.

3. Paton, J. P. J., and Eaton, J. C., Sulfhaemoglobinaemia and methaemoglobinaemia following administration of $\mathrm{p}$-aminobenzenesulphonamide. Lancet, 1937, 1, 1159.

4. Marshall, E. K., Jr., and Walzl, E. M., On the cyanosis from sulfanilamide. Bull. Johns Hopkins Hosp., 1937, 61, 140.

5. Mull, J. W., and Smith, J. T., Effect of sulfanilamide on the oxygen capacity of the blood. J. A. M. A., 1938, 110, 439.

6. Peters, J. P., and Van Slyke, D. D., Quantitative Clinical Chemistry. Vol. II. Methods. Williams and Wilkins Co., Baltimore, 1932, pp. 341, 349, 670. 